\title{
Assessment of Infant Care Practices and Effectiveness of Structured Teaching Programme on 3-6 Month Infant Care in a Selected Ward in Malappuram, India
}

\author{
M. Rathi* \\ Almas College of Nursing, Kottakkal, Malappuram, Kerala, Pin:-676503, India \\ *Corresponding author
}

\begin{abstract}
Ke ywords
Infant care practice, Effectiveness, Structured teaching programme, Structured interview schedule

Article Info

Accepted:

15 January 2019

Available Online:

10 February 2019
\end{abstract}

\section{A B S T R A C T}

Infancy is a critical period in the life of every individual owing to the various adjustments that need to be made for extra uterine survival. Therefore, mortality rates are also very high in this one year period. Good care practices go a long way in reducing morbidity and mortality in this period. A cross sectional study was undertaken on a cohort group of mothers with 3 month old infants to assess their care practices and to determine the effectiveness of a structured teaching programme on good infant care in ward No. 3 of Ponmala Panchayath in Malappuram. Objectives of the study are to assess the infant care practices \& to determine the effectiveness of a structured teaching programme on Good infant care to mothers with 3 month old infants. A total of all available mothers with 3 month old infants (16 Nos.) in the mentioned ward were included in the study. A structured interview schedule was used to assess care practices. After pretest, STP on good infant care was provided. After a period of one week, post test data was collected. Significant desirable practices identified were nonuse of prelacteals (except Mecca Water) and exclusive breast feeding. Significant undesirable practices identified included improper breast feeding technique, use of cradles for night time sleep and use of cold water for infant bath. T test was used to assess effectiveness of STP and it was significant at 0.05 level. This study revealed the prevailing infant care practices and the need for sustained education on infant care.

\section{Introduction}

According to a Report by UNICEF, India has experienced gain towards the fight against infant mortality rates in the country over the last two decades. However, the latest trend does not show the ability of the country in achieving the Millennium Development Goal No.4 which aims at reducing the under-five mortality by two thirds in the period stretching1900 to $2015(1,2)$. Despite the progress, IMR in India is very high. It is estimated that about 400,000 newborns in India die within the first 24 hours of birth. IMR in India varies from state to state. In India, Kerala, Tamilnadu, Maharashtra, Punjab, West Bengal and Himachal Pradesh are registering significant improvements in infant mortality rates $(3,4)$. 
Infant health depends to a large extent on the antenatal and neonatal care received and to a considerable extent on the infant care practices adopted at home: Practices including those on food hygiene, feeding, bathing and comfort, safety and emergency management, play and stimulation are considered as vital components to the healthy growth and development of infants. This study sought to study the prevailing infant care practices in Malappuram District of Kerala.

The main objectives of this study to assess the existing infant care practices prevailing in the selected community. Identification of existing practices for selected infant ailments. And also to assess effectiveness of Structured Teaching Programme on good infant care.

\section{Materials and Methods}

Setting and Subjects: Descriptive research design was used for assessing existing infant care practices using structured interview technique. A pre-experimental approach with one group pretest-posttest design was utilized for assessing effectiveness of STP. A total of 16 mothers who were the only ones available with 3 month old infants in the selected ward of Ponmalapanchayath in Malappuram district were the samples selected by purposive sampling technique.

Tools: In addition to the Sociodemographic data collection tool on mother and infant, a structured interview schedule having five sections related to infant care was used to assess infant care practices namely hygiene practices, comfort practices, feeding practices, safety practices and play and stimulation, an open ended questionnaire for assessing care practices for selected infant ailments and a structured close ended questionnaire with 20 questions under six areas namely growth and development parameter, developmental characteristics, deviation from normal growth and development, common health problems in infants major disease conditions and management and other conditions all relating to good infant care were utilized for the study. Treatment: Conduction of STP on good infant care.

Validity: To ensure content validity, the tool was submitted to experts in the field of pediatrics, pediatric nursing and community health.

Procedure: With the help of local anganwadi teachers, the houses of the mothers were identified. A total of 3 mothers were interviewed in a day. After assessing their infant care practices including those for selected ailments, the pretest questionnaire was dictated to them and their choices recorded. Then the STP was administered using the growth chart and videos on infant care. After a week by which all the mothers had been covered for pretest, post test was conducted in the same order.

The collected data was analysed using descriptive and inferential statistics (Table 6).

\section{Results and Discussion}

The sample characteristics are given in Table 1 and 2.

Table 1 shows that $63 \%$ of the samples were aged 18-25 years, $100 \%$ were Muslims and $56 \%$ had higher secondary education. 94\% were housewives and all 100\% had institutional delivery. Only $12 \%$ had caesarian section done. $13 \%$ mothers had retracted nipple and $44 \%$ of the neonates had jaundice in their first month.

Table 2 shows significant findings such as $81 \%$ infants with birth weight of more than 2500gms., 0\% preterm babies, $12 \%$ infants with birth order of four or more, space 
between children more than 2 years in $75 \%$ infants, $100 \%$ hospital visits for infants with sickness, $81 \%$ immunized appropriately for age, $88 \%$ living in extended families and $69 \%$ families using well water for home and infant use.

Table 3 gives an insight into the practices adopted for common infant ailments. As is seen from the table, majority of the mothers chose to go for homeopathic treatment for the infants since they believed that homeopathic medicines are mild and have no side effects. Tulasi is also found to be predominantly used in the homes for treating fever and cold.

Table 4 highlights significant lapses in infant care that can prove dangerous for infant survival. It also points out the need for sustained health education to the mothers on infant care. Considering that only $25 \%$ of the mothers were primipara, the findings gain more significance. The findings also depict a stereotyped mode of care prevailing in the locality. Mothers who bathed infants in cold water opined that well water was fresh and would strengthen the baby. Similarly putting baby in the cradle is thought to promote good sleep and the danger of suffocation and falls go unnoticed.

Table 5 shows the difference in pre and post test scores on administration of the STP. The findings reflect the ability of the mothers in understanding the information provided to them. $87 \%$ mothers obtained good knowledge in the post test.

Table.1 Demographic characteristics of mother

\begin{tabular}{|c|c|c|c|}
\hline $\begin{array}{c}\text { Sl. } \\
\text { No: }\end{array}$ & Demographic Characteristics & Frequency & $\%$ \\
\hline \multirow[t]{5}{*}{$\mathbf{i}$} & Age & & \\
\hline & a) Less than 18 yrs. & - & \\
\hline & b) $18-25$ yrs. & 10 & 63 \\
\hline & c) $25-35$ yrs. & 6 & 37 \\
\hline & d) Above 25 yrs. & - & \\
\hline \multirow[t]{5}{*}{ ii } & Religion & & \\
\hline & a) Hindu & - & \\
\hline & b) Christian & - & \\
\hline & c) Muslim & 16 & 100 \\
\hline & d) Others & - & \\
\hline \multirow[t]{6}{*}{ iii } & Level of Education & & \\
\hline & a) Nil & - & \\
\hline & b) Primary & - & \\
\hline & c) High school & 5 & 31 \\
\hline & d) Higher secondary & 9 & 56 \\
\hline & e) Graduation \& above & 2 & 13 \\
\hline \multirow[t]{5}{*}{ iv } & Family income per month & & \\
\hline & a) Less than Rs. 1500/- & 2 & 13 \\
\hline & b) Rs. $1500 /-$ to Rs. $3000 /-$ & 5 & 31 \\
\hline & c) Rs.3000/- to Rs 9000/- & 6 & 38 \\
\hline & d) Rs $9000 /-$ to Rs $15000 /-$ & 3 & 19 \\
\hline
\end{tabular}




\begin{tabular}{|c|c|c|c|}
\hline & e) Greater than Rs $15000 /-$ & - & \\
\hline \multirow[t]{6}{*}{$\mathbf{v}$} & Occupation & & \\
\hline & a) Housewife & 15 & 94 \\
\hline & b) Informal work & 1 & 6 \\
\hline & c) Laborer on wages & - & \\
\hline & d) Business / Self Employed & - & \\
\hline & e) Any other & - & \\
\hline \multirow[t]{3}{*}{ vi } & Antenatal checkups & & \\
\hline & a) Regular & 16 & 100 \\
\hline & b) Irregular & - & - \\
\hline \multirow[t]{3}{*}{ vii } & Antenatal period & & \\
\hline & a) Eventful & 4 & 25 \\
\hline & b) Uneventful & 12 & 75 \\
\hline \multirow[t]{4}{*}{ viii } & Place of delivery & & \\
\hline & a) Home & - & - \\
\hline & b) Hospital & 16 & 100 \\
\hline & c) Others & - & \\
\hline \multirow[t]{4}{*}{ ix } & Nature of delivery & & \\
\hline & a) Normal & 14 & 88 \\
\hline & b) Caesarian & 2 & 13 \\
\hline & c) Others & - & - \\
\hline \multirow[t]{3}{*}{$\mathbf{x}$} & Intradelivery problem & & \\
\hline & a) Yes & 2 & 13 \\
\hline & b) No & 14 & 88 \\
\hline \multirow[t]{3}{*}{ xi } & Problem in breast feeding & & \\
\hline & a) Yes & 2 & 13 \\
\hline & b) No & 14 & 88 \\
\hline \multirow[t]{4}{*}{ xii } & Breast feeding & & \\
\hline & a) Not established at all & - & - \\
\hline & b)Stopped before 3 month & - & - \\
\hline & c) Ongoing & 16 & 100 \\
\hline \multirow[t]{3}{*}{ xiii } & Problem in neonatal period & & \\
\hline & a) Yes & 7 & 44 \\
\hline & b) No & 9 & 56 \\
\hline \multirow[t]{3}{*}{ xiv } & Chronically ill parent & & \\
\hline & a) Yes & 1 & 6 \\
\hline & b) No & 15 & 94 \\
\hline \multirow[t]{3}{*}{$\mathbf{x v}$} & Alcoholic parent & & \\
\hline & a) Yes & - & \\
\hline & b) No & 16 & 100 \\
\hline
\end{tabular}


Table.2 Demographic Characteristics of Infant

\begin{tabular}{|c|c|c|c|}
\hline SI No: & Demographic Characteristics & Frequency & $\%$ \\
\hline \multirow[t]{3}{*}{ i } & Sex & & \\
\hline & a) Male & 8 & 50 \\
\hline & b) Female & 8 & 50 \\
\hline \multirow[t]{4}{*}{ ii } & Birth Weight & & \\
\hline & a) Less than $1500 \mathrm{gm}$ & - & \\
\hline & b) $1500 \mathrm{gm}-2500 \mathrm{gm}$ & 3 & 19 \\
\hline & c) Greater than $2500 \mathrm{gm}$ & 13 & 81 \\
\hline \multirow[t]{4}{*}{ iii } & Gestational age & & \\
\hline & a) Preterm & - & \\
\hline & b)Term & 16 & 100 \\
\hline & c)Post term & - & \\
\hline \multirow[t]{5}{*}{ iv } & Birth order & & \\
\hline & A) First child & 4 & 25 \\
\hline & B) Second child & 6 & 38 \\
\hline & C) Third child & 4 & 25 \\
\hline & D) Fourth And above & 2 & 12 \\
\hline \multirow[t]{3}{*}{$\mathbf{v}$} & Age of previous child & & \\
\hline & a) $1-2$ years & 4 & 25 \\
\hline & b) More than 1-2 years & 12 & 75 \\
\hline \multirow[t]{3}{*}{ vi } & Hospital visit for sickness & & \\
\hline & a) Yes & 16 & 100 \\
\hline & b) No & - & \\
\hline \multirow[t]{3}{*}{ vii } & Immunized appropriately for age & & \\
\hline & a) Yes & 13 & 81 \\
\hline & b) No & 3 & 19 \\
\hline \multirow[t]{4}{*}{ viii } & Type of family & & \\
\hline & a) Nuclear & 2 & 12 \\
\hline & b) Extended & 14 & 88 \\
\hline & c) Single & - & \\
\hline \multirow[t]{3}{*}{ ix } & Type of house & & \\
\hline & a) Single & 16 & 100 \\
\hline & b) Colony & - & \\
\hline \multirow[t]{4}{*}{$\mathbf{x}$} & Power supply & & \\
\hline & a) Electricity & 16 & 100 \\
\hline & b) Solar & - & \\
\hline & c) Nil & - & \\
\hline \multirow[t]{6}{*}{$\mathbf{x i}$} & Water Supply & & \\
\hline & a. $\quad$ Protected supply & - & \\
\hline & Well water / Spring & 11 & 69 \\
\hline & Stream / River water & - & \\
\hline & Pond / Lake & - & \\
\hline & Others & 5 & 31 \\
\hline
\end{tabular}


Table.3 Care practices on infant ailments

\begin{tabular}{|c|c|c|}
\hline SINo: & Infant Ailments & Frequency \\
\hline \multirow[t]{6}{*}{ i } & Fever & \\
\hline & a) Thulasi & 7 \\
\hline & b) Homeopathy & 5 \\
\hline & c) Allopathy & 3 \\
\hline & d) Panikoorka & 1 \\
\hline & e) cold application & 2 \\
\hline \multirow[t]{6}{*}{ ii } & Diarrhea & \\
\hline & a) Homeopathy & 8 \\
\hline & b) Allopathy & 4 \\
\hline & c)Conjee & 1 \\
\hline & d) Lime \& salt & 1 \\
\hline & e)Panikoorka & 2 \\
\hline \multirow[t]{5}{*}{ iii } & Common cold & \\
\hline & a) Homeopathy & 9 \\
\hline & b)Thulasi & 5 \\
\hline & c) Allopathy & 2 \\
\hline & d) Vayambu\&Masikka & 1 \\
\hline \multirow[t]{4}{*}{ iv } & Abdominal colic & \\
\hline & a) Homeopathy & 10 \\
\hline & b) Allopathy & 5 \\
\hline & c) Palkayam & 1 \\
\hline \multirow[t]{5}{*}{$\mathbf{v}$} & Constipation & \\
\hline & a) Homeopathy & 9 \\
\hline & b) Allopathy & 5 \\
\hline & c)Soaked dry grapes & 2 \\
\hline & d)Brahmi juice & 1 \\
\hline
\end{tabular}

Note: One respondent may give more than one option.

Table.4 Undesirable care practices identified

\begin{tabular}{|c|l|c|l|}
\hline SI No: & \multicolumn{1}{|c|}{ Practices } & Frequency & \multicolumn{1}{|c|}{$\%$} \\
\hline $\mathbf{a}$ & Not covering head & 15 & 94 \\
\hline $\mathbf{b}$ & Bathing infant in cold water & 12 & 75 \\
\hline $\mathbf{c}$ & Putting baby to sleep in the cradle all night & 16 & 100 \\
\hline $\mathbf{d}$ & Not observing infant all time & 12 & 75 \\
\hline $\mathbf{e}$ & Ignorance of ORS & 16 & 100 \\
\hline $\mathbf{f}$ & Ignorance of expulsion of foreign body from throat & 15 & 94 \\
\hline $\mathbf{g}$ & Ignorance of prevention of milk aspiration & 16 & 100 \\
\hline $\mathbf{h}$ & Ignorance on prevention and management of febrile fits & 11 & 69 \\
\hline $\mathbf{i}$ & Ignorance of danger signs in infants & 14 & 88 \\
\hline
\end{tabular}


Table.5 Difference in pre and post-test level of knowledge scores

\begin{tabular}{|c|c|c|c|c|}
\hline Test & & Good & Average & Poor \\
\hline \multirow{2}{*}{ Pretest } & Frequency & - & 9 & 7 \\
\cline { 2 - 5 } Post-test & \% & - & 56 & 44 \\
\cline { 2 - 5 } & Frequency & 14 & 2 & - \\
\hline
\end{tabular}

Table.6 Effectiveness of structured teaching programme

\begin{tabular}{|l|l|l|l|l|l|l|}
\hline \multicolumn{1}{|c|}{ Knowledge Test } & \multicolumn{1}{|c|}{ Mean } & \multicolumn{1}{c|}{ SD } & \multicolumn{1}{c|}{ MD } & \multicolumn{1}{c|}{ CI } & t value & P Value \\
\hline Pretest & 9.37 & 2.75 & 7.5 & $7.91-10.84$ & 10.19 & $<.05$ \\
\hline Post test & 16.87 & 1.75 & & $15.94-17.81$ & & \\
\hline
\end{tabular}

$\mathrm{t}(15) \geq 2.131, \mathrm{P}=0.05$

The overall findings on infant care practices indicate that they indeed play a major role in mortality and morbidity of infant population and need to be addressed in a concerned manner.

In conclusion, assessment of infant care practices is a vital need of the hour to strike hard at infant morbidity and mortality at the ground level. Health care professionals should imperatively hold infant care practice assessment and education as an essential component of $\mathrm{MCH}$ care.

\section{References}

1. Rentala Sreevani (2019). Basics in Nursing Research and Biostatistics. New Delhi: Jaypee Brothers Medical Publishers.

2. Votroubek Wendy, Aaron Tabaco (2010) Pediatric Home Care for Nurses.London: $3^{\text {rd }}$. Ed., Jones and Barlett Publishers International.

3. www.socialresearchmethods.net

4. http://nhm.gov.in/nrhmcomponents/rmnch-a/child-healthimmunization/childhealth/guidelines.html

\section{How to cite this article:}

Rathi, M. 2019. Assessment of Infant Care Practices and Effectiveness of Structured Teaching Programme on 3-6 Month Infant Care in a Selected Ward in Malappuram, India. Int.J.Curr.Microbiol.App.Sci. 8(03): 1949-1955. doi: https://doi.org/10.20546/ijcmas.2019.803.231 